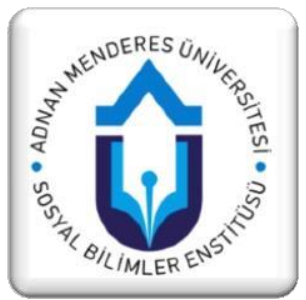

\title{
Mütareke ve Milli Mücadele Yıllarında Aydın ve Menteşe Sancaklarında Yapılan Seçimler
}

\author{
Aslıhan KILINÇ1
}

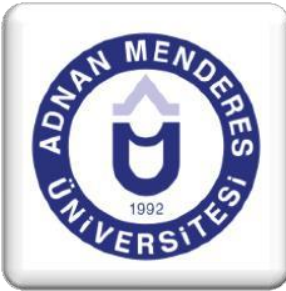

Özet

XIX. yüzyıl sonunda Meşrutiyet düşüncesi Osmanlı İmparatorluğu'nda giderek güçlenmiş ve Sultan II. Abdülhamid 23 Aralık 1876'da Kanun-1 Esasi'yi ilan etmiștir. Türk tarihinin ilk modern anayasası olan Kanun-1 Esasi'nin ilanından sonra ilk Mebusan Meclisi 1877 yılında açılmış ancak 1877 Osmanlı-Rus savaşının çıkmasından sonra Sultan II. Abdülhamid tarafından otuz yıla yakın süre tatil edilmiştir. 1908 yılında Meşrutiyet'in tekrar ilan edilmesi ile açılan meclis 1918 Aralık ayına kadar görev yapmışıı. 1919 yılında tekrar seçimlere giden Osmanlı İmparatorluğu'nda Son Osmanlı Mebusan Meclisi seçimleri 7 Ekim 1919'da Ali Rıza Paşa Hükümeti'nin seçim kararı almasıyla resmi olarak başlamıştır. Özellikle Batı Anadolu'da yaşanan ağır işgaller nedeniyle seçimlerin bu bölgelerde yapılması pekte kolay olmamıştır. Bunlar arasında henüz Yunan işgali altına girmemiş, Menderes'in güneyi İtalyan işgali altında olan Aydın ve Menteşe Sancaklarında diğer işgal güçlerine nazaran daha 1lımlı bir politika izlendiği için seçimler yapılabilmiştir. Bu iki bölgede yapılan seçimler sonucunda Osmanlı Mebusan Meclisine Aydın'dan üç Menteșe'den de iki olmak üzere beș mebus seçilmiștir. Hüseyin Kazım (Kadri) Bey, Cami (Abdülkadir Cami Baykurt) Bey, Emin Bey Aydın'dan seçilirken, Mustafa Hilmi (Uran) Bey ve Halil İbrahim Efendi Menteșe sancağından seçilen mebuslardır. 12 Ocak 1920 tarihinde Son Osmanlı Mebusan Meclisi toplanmış ve 16 Mart 1920 tarihinde İngilizler tarafından işgal edilinceye kadar yirmi dört oturum yapmıştır.

Anahtar Kelimeler: Aydın, Menteşe, Efelerin Mücadelesi, Sivas Kongresi, Seçimler

\section{Elections Made İn Aydın And Menteșe Sanjaks During The Armistice And The The Years Of National Struggle}

\begin{abstract}
At the end of the XIX. century, Constitutionalism thought gradually gained strength in the Ottoman Empire and Sultan II. Abdulhamid declared the Basis of Law on December 23, 1876. The first Parliamentary Assembly was opened in 1877 after the announcement of the Law-i Esasi, the first modern constitution in Turkish history, but after the 1877 Ottoman-Russian war broke out, Sultan II. Abdulhamid took a vacation for nearly thirty years. The parliament, which was opened with the declaration of the Constitutional Monarchy in 1908, served until December 1918. In the Ottoman Empire, which went to elections again in 1919, the last Ottoman Parliamentary Assembly elections officially started on October 7, 1919 with the election decision of the Ali Riza Pasha Government. It was not easy to hold elections in these regions, especially due to the heavy occupations in Western Anatolia. Among these, elections were held in Aydın and Menteşe Sancaks, which were under Italian occupation in the south of Menderes, because of a more moderate policy than other occupation forces. As a result of the elections held in these two regions, five deputies, three from Aydın and two from Menteşe, were elected to the Ottoman Parliament. While Hüseyin Kazım (Kadri) Bey, Cami (Abdülkadir Cami Baykurt) Bey, Emin Bey were elected from Aydın, Mustafa Hilmi (Uran) Bey and Halil İbrahim Efendi were the members of the Menteșe Sanjak. The Last Ottoman Parliament convened on 12 January 1920 and held twenty-four sessions until it was occupied by the British on 16 March 1920.
\end{abstract}

Key Words: Aydın, Menteşe, Struggle Efe's, Sivas Congress, Elections

\footnotetext{
${ }^{1}$ Dr. Aslıhan Kılınç, asl-han-7701@ @otmail.com, https://orcid.org/0000-0001-8928-2961
} 


\section{Giriş}

I. Dünya savaşından sonra Osmanlı topraklarında tam bir kargaşa yaşanmıştır. Bir tarafta mütareke gereği feshedilen bir meclis, işgal edilen topraklar ve tüm bunlara sessiz kalmay1 tercih eden bir payitaht, diğer tarafta ise Türk Milletinin bağımsızlık mücadelesini örgütlemeye çalışan Mustafa Kemal Paşa vardır. 1919 yılının ilk yarısında ülkenin genel durumunu böyle özetlemek mümkündür. Mustafa Kemal Paşa İzmir'in işgal edilmesinden sonra İstanbul Hükümeti'nin yaşanan işgaller karşısında sessiz kalmasına daha fazla kayıtsız kalamamış ve Samsun'a çıkarak kurtuluş mücadelesini başlatmıştır.

Mustafa Kemal Paşa'nın Samsun'a çıktıktan sonra ilk işi Amasya Genelgesi'ni yayınlamak olmuştur. Akabinde kongreler için hazırlıklara başlamış, Erzurum ve Sivas Kongreleri toplanarak Kurtuluş Savaşı'nın komuta kademesi (Temsil Heyeti) oluşturulmuştur. Daha sonar sıra seçimlerin yapılmasına gelmiştir. Temsil Heyeti'ne göre biran önce meclis açılmalıdır. Ancak ülkenin işgal altında olması bunun pekte kolay olmadığını göstermektedir. Aynı şekilde Aydın Vilayeti de işgal altında olduğu için yapılacak 1919 seçimleri hem Temsil Heyeti'ni hem de İstanbul Hükümeti'ni oldukça endişelendirmektedir. Dahası Temsil Heyeti'nin bölgedeki tek endişesi sadece işgalciler ve İstanbul Hükümeti'nin muhalif tutumu değildir. Aydın Valisi Ahmet İzzet Bey'de seçimler için büyük bir engel teşkil etmektedir. Zira vali İstanbul Hükümeti’nin güttüğü Milli Mücadele karşıtı politikayı açıkça desteklemkte ve Yunan Generali Nider'in seçimlerin iptal edilmesi için verdiği talimatlara da harfiyen uymaktadır (Karaca,2004:334). Oda tıpk1 İstanbul Hükümeti gibi Mustafa Kemal Paşa ve Kuvâ-yı Milliye hareketini Damat Ferit Paşa Kabinesinin ve İngilizlerin siyasi amaçlarına ulaşmasında önemli bir engel olarak görmektedir. Bu yüzden vilayet sınırları içerisinde Milli Mücadele hareketine katılan kim varsa ya İttihatçılıkla ya da Bolşeviklik ile suçlayarak bertaraf etmeye çalışmıştır (Bilgen,2010:60).

Temsil Heyeti valinin bu faaliyetleri karşısında, öncelikle Sivas Kongresine delege gönderilmesi ve ardından seçimlerin yapılması için vilayette yoğun bir çalışma başlatmıştır. Ancak bu kez de karşılarına efelerin nüfuz mücadelesi çıkmıştır. Zira bölgede oldukça önemli bir güce sahip olan efeler Batı Anadolu bölgesinde Kuvâ-yı Milliye harekâtının da bel kemiğidir. Temsil Heyeti'nin Aydın ve civarındaki merkezlerin birçok faaliyeti efeler sayesinde yürütülmektedir. Özellikle Demirci Mehmet Efe ve Yörük Ali Efe'nin Menteşe havalisi üzerindeki nüfuz çekişmesi Kuvâ-yı Milliye çalışmalarını zora sokmuştur. Sivas Kongresi'ne delege yollama yarışı ve seçimlerde mebus çıkarma mücadelesi işgal döneminde Aydın havalisini her yönden olumsuz etkilemiştir.

\section{Milli Mücadelede Efelerin Mücadelesi}

Milli Mücadele hareketinin etkili güçlerinden biri de milis kuvvetlerdir. Özellikle Batı Anadolu Bölgesinde teşkilatlanan efelerin kızan sayısı azımsanmayacak kadar fazladır. Kimi zaman aralarındaki mücadele hem halka hem de hükümete yansımış olsa da efeler Temsil Heyeti ve Mustafa Kemal Paşa tarafında yer almasını bilmiştir. Demirci Mehmet Efe Aydın bölgesinde güç olarak Yörük Ali Efe'den daha nüfuzludur. Öyle ki Müdafaa-i Hukuk Merkezleri onun haberi olmadan Aydın ve havalisinde önemli kararlar alamamıştır. Bununla birlikte bölgede yüksek rütbeli subayların olmaması da Demirci Mehmet Efe'nin bölgede söz sahibi olmasını kolaylaştırmıştır diyebiliriz. Bu durum Mustafa Kemal Paşa tarafından ele alınmış ve bölgede ki koordinasyonu sağlamak için Aydın Kuvâ-yı Milliye Komutanlığı'na Refet (Bele) Paşa'yı görevlendirmiştir. Nitekim Refet Paşa Demirci Mehmet Efe'den komutanlığı almak yerine onunla birlikte hareket etmeye başlamıştır (Gökbel, 2005:308310). 
Aslında bu dönemde Demirci Mehmet Efe ile Yörük Ali Efe'nin aralarının açık olduğu bilinmektedir. Dahası efelerin güç mücadelesi Sivas Kongresi hazırlıkları sırasında iyiden iyiye hissedilmiş ve bu süreçte yaşanan olumsuz gelişmeler Meclis-i Mebusan seçimlerine de yansımıştır. Efeler arasında yaşanan gerginliğin başlangıç noktası Hamza ve Ragıp Beylerin Kuvâ-yı Milliye için ortak karar alarak Menteşe Mutasarrıfı Serficeli Hilmi Bey’i Sivas Kongresi'ne yollaması olmuştur. Hilmi Bey'in gönderilmesinden sonra Hamza Bey 27 Ekim 1919 tarihinde Nazilli'de milis komutanı Yörük Ali Efe ile görüşmüş ve bir süre efe'nin yanında kalmıştır. Bu yakınlaşma Muğla Kuvâ-yı Milliye birliklerini rahatsız etmiş, Ragıp Bey, Yörük Ali Efe ve amcası Hamza Bey'in işbirliğine karşı Demirci Mehmet Efe'nin birliklerinden Leyneli Yüzbaşı Cavit Bey’den yardım istemiştir. Böylece Demirci Mehmet Efe'de olaylara dâhil olmuştur. Bunun üzerine Yüzbaşı Cavit Bey'in komutasındaki birlikler 27 Kasım 1919 tarihinde Yörük Ali Efe'nin bulunduğu Bekir Ağa Köşkü'ne girmiş, çıkan kargaşada Muğla'nın ileri gelenlerinin uzun uğraşlarından sonra anlaşma sağlanmıştır. Aslında burada mücadele edenler efeler değil Hamza Bey ve Ragıp Bey'dir (Akça,2000:2831).

Mustafa Kemal Paşa da efelerin mücadelesinin farkındadır. Ancak bölgeyi kontrol altında tutmak ve halkın ihtiyaçlarının karşılanması konusunda efelerin üstlendiği rolü bildiği için Refet Paşa ile sık sık görüşerek efelerin bölgedeki gücünü kontrollü bir şekilde kullanmaya çalışmıştır. Refet Paşa'ya çektiği telgraflarla bölgedeki durum hakkında bilgi almıştır. Aslında Mustafa Kemal Paşa'nın telgraflarında açıkça sormadığı ama merak ettiği mesele efelerin bölgede asayişi ne derece sağlayabildiğidir. Zira bölgede önemli bir statüsü olan efelerin etrafında azımsanmayacak sayıda milis kuvveti bulunmaktadır. Bu nedenle Mustafa Kemal Paşa telgrafında Refet Paşa'dan kendisine efelerin Milli Mücadele'ye karşı duruşu hakkında açıkça rapor vermesini istemiştir. Refet Paşa'dan bölgede bulunduğu bu süre zarfında çok dikkatli bir şekilde olayları gözlemlemesini ve özellikle Demirci Mehmet Efe'nin milis kuvvetleri hakkında fikirlerini rapor halinde sunmasını istemiștir. Aslında Mustafa Kemal Paşa Demirci Mehmet Efe'nin Milli Mücadele için çalışmalarından memnundur. Ancak emir ve kumanda konusunda efenin bir yere kadar yetki almasının doğru olacağını düşünmektedir. Kısacası bölgede Müdafaa-i Hukuk Merkezleri üstünde güç istememektedir. Bu yüzden Refet Paşa'dan çevresinde olanları dikkatle gözlemlemesini, efeleri de gücendirmeden ağızlarını aramasını sonra da durumu kendisine bildirmesini istemiştir (ATASE Arşivi, Atatürk Koleksiyonu, K:24, G:96, B:96an; ATASE Arşivi, Atatürk Koleksiyonu, K:24, G:96, B: 96aq).

\section{Sancaklarda Sivas Kongresi Hazırlıkları}

Erzurum Kongresi'nde Sivas Kongresi'ne katılmak üzere her sancaktan üç delege seçilmesi kararlaştırılmıştır. Buna mukabil Batı Anadolu ve Trakya bölgelerinin ağır işgal altında olması delege seçimlerini zorlaştırmış hatta bazı bölgelerde imkânsız kılmıştır (Tosun,1996:77). Aydın merkez ve Menteşe Sancaklarında ise durum biraz daha farklıdır. $\mathrm{Bu}$ bölgeler ağırlıklı olarak İtalyanlar tarafından işgal edildiği için delege seçimleri diğer işgal bölgelerine nazaran daha rahat yapılabilmiştir. Buna mukabil burada yapılan delege seçimleri de Yörük Ali ve Demirci Mehmet Efe'lerin güç mücadelesinin gölgesinde yapılmak zorunda kalmıştır. Her ikisi de Sivas Kongresi'ne kendi adaylarının gönderilmesini istemiş ve bu mücadele daha önce de belirttiğimiz gibi1919 seçimlerine giden süreçte sancaklardaki genel durumu olumsuz etkilemiştir. Bununla birlikte Aydın Vilayetinde telgraf hatlarında yaşanan sorun ve telgrafların bölgeye bir ay gecikmeli ulaşması da bu iki sancağın delegelerinin Sivas'a geç ulaşmasına neden olmuştur. Mustafa Kemal Paşa'ya sadık subaylar arasında yer alan 57. Tümen Komutanı Albay Mehmet Şefik Aker'in hatlarda yaşanan gecikmenin sebebinin farkına varmasıyla sorun çözülmüş ve geçte olsa seçilen delegeler 
Sivas Kongresi’ne gönderilmiștir. Albay Şefik Aker telgrafların gecikmesiyle kongre ve seçim hazırlıklarının henüz başlatılmamış olmasından dolayı duyduğu üzüntüyü Sivas'a çektiği bir telgrafla Mustafa Kemal Paşa'ya bizzat bildirmiştir. Telgrafinda Sivas'tan kendilerine gönderilen 13 Eylül 1919 tarihli telgrafın bir aya yakın bir süre sonra yani 10 Ekim 1919 tarihinde ellerine ulaştığını bildirmiştir. Telgrafında ayrıca 57 Tümen bölgesinde sadece Denizli ve Aydın sancaklarında kongre hazırlığı ve milletvekili seçimlerine dair bir emir almadıklarını belirtmiştir. Albay Şefik Aker daha sonrada 23 Ekim'de tekrar Mustafa Kemal Paşa'ya bir telgraf çekerek kendisinin telgrafhanelerdeki aksaklık yüzünden yanlış anlaşılmasından korktuğunu ve yaşanılan bu aksaklığın başka sebeplerden kaynaklandığını belirtmiştir:

"Aydın çevresindeki Milli Mücadele ne şekilde cereyan ettiği hakkında bilgi vermek, içinde bulunduğum sıkıntıl durumun kendilerine kadar yaylması ihtimaline karşı kendimi tanıtmak ve vatanın kurtarılması yolundaki çalışmalarına bağglılığımı arz etmek üzere, 23 Ekim 1919 tarihinde yazdı̆̆ım ayrıntılı yazıyı posta ile gönderdim."

Mustafa Kemal Paşa Aker'in bu telgrafina 17 Kasım'da gönderdiği cevapla ona duyduğu güveni dile getirmiştir ve çalışmalarının devamını dilemiştir (Aker,2006:301-302). Haberleşmede ki sorun halledilmiş ve Aydın, Menteşe Havalisi Kuvâ-yı Milliye Umum Kumandanı Hacı Süleyman Efendi 26 Ekim 1919 tarihinde, Mustafa Kemal Paşa'ya çektiği telgrafla Aydın ve Menteşe bölgelerinde delege seçimlerinin bittiğini ve Menteşe Mutasarrıf Hilmi Bey, Nazilli eşrafindan Hacı Süleyman Bey, Ulemayı Namdan Denizli müftüsü Ahmet Hulûsi Efendi ile Aydın eşraf ve Handan-ı Kadimden Kazım Nuri Bey'in delege olarak seçildiğini bildirmiştir. Hacı Süleyman Efendi telgrafın devamında seçilen delegelerden Milli Mücadele fikrine son derece bağlı ve güvenilir kişiler diye bahsetmiş ve bu isimlerin kongrede başarılı olunacağını ümit ettiğini eklemiştir (ATASE Arşivi, Atatürk Koleksiyonu, $\mathrm{K}: 24, \mathrm{G}: 96, \mathrm{~B}: 96 \mathrm{ad})$.

Demirci Mehmet Efe'de 26 Ekim 1919'da Sivas'a çektiği telgrafla Menteşe Mutasarrıfı Hilmi Bey, Nazilli ulemasından Hacı Süleyman Efendi ve Aydın eşrafından Kazım Nuri Bey'in delege olarak Nazilli'den Sivas'a doğru hareket ettiğini doğrulamıştır. Telgrafin devamında delegelerin Sivas'a, Konya, ya da Ulukışla yollarından hangisi ile gitmesinin uygun olduğunun 3. Kolordu Komutanı Refet Paşa'ya sorulmasını istemiştir. Ayrıca delegelerin Konya yada Ulukışla üzerinden Sivas'a geçeceğini ve eğer imkân varsa delegelerin götürülmesi için bir otomobil tahsis edilmesini de talep etmiştir (ATASE Arşivi, Atatürk Koleksiyonu, K:24, G:96, B:96ae; ATASE Arşivi, Atatürk Koleksiyonu, Kol. K:24, G:96, B:96aea; ATASE Arşivi, Atatürk Koleksiyonu, K:24, G:96, B:96ah ).

Demirci Mehmet Efe ile Hacı Süleyman Efendi'nin telgrafları Sivas'a ulaşmıştır. Ancak her ikisinin de verdiği isimler aynı değildir. Hacı Süleyman Efendi Sivas'a gönderilmek üzere seçilen delegeler arasında Denizli Müftüsü Ahmet Hulûsi Efendi'nin ismini de vermektedir. Oysa hem Demirci Mehmet Efe'nin hem de Kayseri Mutasarrıfi Vekili Abidin Bey'in telgraflarında Ahmet Hulûsi Efendi yoktur. Bununla birlikte 4-11 Eylül 1919 tarihinde yapılan toplantı tutanaklarında Ahmet Hulûsi Efendi'nin ismi bulunmamaktadır. Dolayisıyla Hacı Süleyman Efendi'nin telgrafında bir bilgi hatası yapılmış olması kuvvetle muhtemeldir. Sonuç itibarı ile delegelerin isimleri Sivas'a ulaşmış ve Sivas'tan Afyon, Niğde Konya Mutasarrıflıklarına çekilen telgraflarla Mutasarrıf Hilmi Bey'in, Hacı Süleyman Efendi'nin ve Kâzım Nuri Bey'in, Aydın bölgesinden delege olarak Sivas'a doğru teşrif etmekte oldukları haber edilmiştir. Ayrıca delegelerin Ulukışla üzerinden, Ulukışla-Sivas arasında işleyen Amerikan otomobillerinden de faydalanmaları için gerekenin yapılacağ bildirilmiştir (ATASE Arşivi, Atatürk Koleksiyonu, K:24, G:96, B:96ak). 
Aydın'dan gönderilen bu haberlerden 5 gün sonar, 31 Ekim'de, Kayseri Mutasarrıf Vekili Abidin Bey de Mustafa Kemal Paşa'ya bir telgraf çekmiş ve delegelerin yola çıktığını haber etmiştir. "Aydın ve Havâlisi Umûm Kumandanlı̆̆ı tarafindan murahhas olaraki'zâm kılınan Menteşe Mutasarrifi Hilmi Bey ile iki refiki bugün Salı sabâh otomobil ile Sivas'a hareket ettiler” (ATASE Arşivi, Atatürk Koleksiyonu, K:24, G:96, B:96aj). Aydın'dan yola çıkan delegelerin Kasım ayı ortasında Sivas'a varmasından sonra Mustafa Kemal Paşa Nazilli'de bulunan Refet Paşa'ya bir telgraf çekerek Demirci Efe'nin gönderdiği delegelerin Sivas'a geldiğini ve delegelerden bölgenin durumuyla alakalı bazı bilgiler aldığını bildirmiştir (ATASE Arşivi, Atatürk Koleksiyonu, K:24, G:96, B:96an; ATASE Arşivi, Atatürk Koleksiyonu, K:24, G:96, B:96aq).

\section{Aydın Sancağında Seçim Sürecinin Bașlaması}

Vilayet ve sancak merkezlerinden seçilen delegelerin Sivas'a ulaşmasıyla Sivas Kongresi 4 Eylül 1919 tarihinde başlamış ve Mustafa Kemal Paşa başkan seçilmiştir (Nutuk, 2016:77). Yukarıda belirttiğimiz üzere Aydın ve Menteşe'den seçilen delegeler çok daha sonra Sivas'a geçerek Mustafa Kemal Paşa ile görüşmüştür. Bununla birlikte kongrede üzerinde durulan en önemli konu Mebusan Meclisinin açılması olmuştur (Çolak,2015:191). Temsil Heyeti, İstanbul Hükümeti'ne Yunanistan ve İtalyan işgalinde olan Batı Anadolu bölgelerinde bir an önce seçimlerin yapılması için baskı yapmış ve uyarıda bulunmuştur. (Karaca,2004:331) Bu süre zarfında Temsil Heyeti'nin baskılarına dayanamayan Damat Ferit Paşa 1 Ekim 1919 tarihinde istifa etmiş, bu durum Temsil Heyeti ve halk tarafindan memnuniyetle karşılanmıştır (Güneş,2012:239; Bilgen,2011:11). Daha sonra 3 Ekim 1919 tarihinde Ali Rıza Paşa Hükümeti kurulmuş ve böylece Türk Milli Mücadele tarihinde yeni bir dönem başlamıştır (TİTE Arşivi, K:297, G:49, B:49-1; Güneş,2012:239). Ali Rıza Paşa Hükümeti'nin 9 Ekim 1919 tarihinde seçim kararnamesini yayınlamasından sonra sıra seçim kanununun hazırlanması ve seçimin yapılmasına gelmiştir (Demiryürek,2018:526).

Dâhiliye Nezaretinin 16 Ekim 1919 tarihinde vilayet ve sancak merkezlerine seçimlerde uyulması gereken kuralları bildiren yazısının ulaşmasından sonra 1919 seçim süreci Aydın ve Menteşe Sancaklarında da başlamıştır (BOA. DH. İ.UM. EK. D:114, G:39-16). Mustafa Kemal Paşa ise olacakları önceden görmüş ve daha önce Sivas Kongresi'nde seçim konusunu ele almıştır. Akabinde hemen Müdafaa-i Hukuk Merkezlerine seçimlerde yapılması gerekenleri bildirmiştir. Seçim genelgesinin gönderildiği tarihlerde Aydın özellikle Yunanlılar tarafından ağır işgallere maruz bırakılmaktadır. Bölge aynı zamanda İtalyanlar tarafindan da işgal edilmiştir. Ancak daha önce de belirttiğimiz üzere İtalyanlar burada diğer işgalcilere nazaran daha 1lımlı bir politika izlemiştir. Batılı devletler ise Yunan işgallerini sadece eleştirmekle yetinmiştir (Öztoprak,1989:47). Bu işgaller altında Aydın Sancağında seçim hazırlıkları başlamış ve Temsil Heyeti tarafindan bu bölgelerden seçilmesi uygun olan isimlerin biran evvel belirlenmesi ve Sivas'a bildirilmesi istenmiştir (ATASE Arşivi, Atatürk Koleksiyonu, K:20, G:206, B:206-bo).

Mustafa Kemal Paşa tarafından 10 Ekim 1919 tarihinde sancak merkezlerine gönderilen bildiri Aydın Sancağına da ulaşmış ve Temsil Heyeti adına Mustafa Kemal Paşa, Aydın Mutasarrıflığından hükümet tarafından alınan seçim kararına harfiyen uyulmasını istemiştir. Bunun yanında sancakta Müdafaa-i Hukuk Merkezinin ne derece teşkilatlandığının belirlenmesini ve ayrica sancaktan ismi belli olan adayların derhal Sivas'a bildirilmesini emretmiştir (ATASE Arşivi, Atatürk Koleksiyonu, K:20, G:206, B:206-ad). 11 Ekim 1919'da Sivas'tan Selahattin Bey de Ali Fuat Paşa'ya bir telgraf çekerek Aydın'dan Temsil Heyeti adına aday olacak isimlerin biran önce belirlenmesini istemiştir (TITE Arşivi, K:310, G:44, B:44-1; ATASE Arşivi İstiklal Harbi Kataloğu, K:1, G:77). Telgrafların sancağa ulaşmasından sonra Aydın Müdafaa-i Hukuk Merkezinden Hüseyin Avni Bey, Mustafa 
Kemal Paşa'nın teşkilatlanma çağrısına cevap olarak 16 Ekim'de Sivas'a bir telgraf göndermiş ve Kuvâ-yı Milliye esaslarına göre hareket ederek Temsil Heyeti tarafinda yer alacaklarını bildirmiştir. Zira Temsil Heyeti için bu çağrıların karşılık bulması oldukça önemlidir. Seçimlerin kazanılabilmesi için ülke genelinde öncelikle sancak merkezlerinde kurulan ve yerel birliklerden oluşan Müdafaa-i Hukuk Merkezlerinin sık1 bir şekilde teşkilatlanması gerekmektedir (ATASE Arşivi, Atatürk Koleksiyonu, K:2, G:58, B:58ac).

Yukarıda belirttildiği Aydın Vilayeti genelinde telgraf hatlarında yaşanan sorunun giderilmesinden sonra Aydın Sancağında seçim hazırlıkları tam anlamıyla başlamıştır. Ancak sancakta seçimler için hazırlık yapan sadece Temsil Heyeti ve İstanbul Hükümeti değildir. Yörük Ali Efe başta olmak üzere Demirci Mehmet Efe ve Hasan Hüseyin Efeler de seçim sürecinde (Haytoğlu,2011:56) bölgelerinde kurulan Müdafaa-i Hukuk Merkezlerinin temsilcileri olarak seçim hazırlıklarına başlamıştır. Bunlar arasında en güçlü olan Demirci Mehmet Efe Sivas'a Mustafa Kemal Paşa'ya çektiği telgraflarla hem işgaller karşısında Aydın bölgesindeki savunma faaliyetleri hakkında (ATASE Arşivi, Atatürk Koleksiyonu, K:24, G:96, B:96aea) hem de Türklerin Yunanlılardan geri aldıkları bölgelerde Rumları katledeceği şeklinde asılsız haberler yaymaya çalışan Rumlar hakkında bilgi vermiştir (ATASE Arşivi, Atatürk Koleksiyonu, K:24, G:96, B:96ai). Seçim arifesinde yaşanan bu kargaşa Temsil Heyeti adına olumsuz sonuçlar doğurabilirdi. Bu yüzden çıkan olaylar, halkın huzuru bozulmadan biran önce bastırılmalı ve halkın tek gündem maddesi seçimler olmalıydı. Görüldüğü üzere Aydın'da genel durum oldukça karışıtır. Yine de seçimler başlamıştır. Kayıtlara göre Aydın'dan ilk olarak Çiftçiler Fırkasının adayları belli olmuştur. Çiftçiler Fırkası 23 Ekim 1919 tarihinde Doktor Mustafa Hulusi Bey gözetiminde toplanmış ve intihap encümeninin aldığı karar sonucu adaylarını belirlemiştir. Buna göre emekli Miralay Hafız Reşit Bey ve Ziraat Mütehassısı Salih Zeki Bey Çiftçiler Fırkası adına Aydın'dan aday gösterilmiştir (Yenigün, 24 Teşrinievvel 1335, s.3).

Ekim ayı sonlarında sancaktan Temsil Heyeti'nin adayları da belli olmaya başlamıştır. Aday olarak gösterilen isimler, Aydın ve Menteşe Kuvâ-yı Milliye Umum Kumandanı Hacı Süleyman Efendi tarafindan Mustafa Kemal Paşa'ya bir telgrafla bildirilmiştir. Buna göre sancaktan Sivas'a delege olarak gönderilen Menteşe Mutasarrıfı Hilmi Bey, Duhûl-1 Ulemadan ve Nazilli eşrafından Hacı Süleyman Efendi, Ulemâ-yı Nâmdan Denizli Müftüsü Ahmet Hulûsi ve Aydın eşrafından Kazım Nuri Bey aday olarak gösterilmiştir. Bu isimler sancaktan mebus olarak seçilmesi uygun kişilerdir. Hacı Süleyman Efendi Mustafa Kemal Paşa'ya gönderdiği bu şifrede ayrıca bu isimler hakkında bazı bilgiler de vermiştir. Sivas'a delege olarak gönderilen isimlerin adaylığı Temsil Heyeti tarafından da kabul edilince adaylıkları Kabul edilmiştir (ATASE Arşivi, Atatürk Koleksiyonu, K:24, G:96, B:96ad). Ancak adaylar konusunda Denizli Müftüsü Ahmet Hulûsi Bey tarafından gönderilen başka bir telgraf Sivas'ta akılları karıștırmıştır. Denizli Mutasarrıfı Tevfik Bey tarafından Sivas'a ulaştırılan bu telgrafta Kazım Nuri Bey hakkında olumlu bilgiler verilirken onunla birlikte adı zikredilen Menteşe Mutasarrıfı Hilmi Bey ve Nazilli eşrafından Hacı Süleyman Efendi'nin ise güvenilmeyecek kişiler olduğundan bahsedilmiştir (ATASE Arşivi, Atatürk Koleksiyonu, K:24, G:96, B:96asa). Tevfik Bey'in bu telgrafina Sivas'tan nasil bir yanit verildiği bilinmemektedir. Ancak seçim çalışmalarını bu denli sıkı tutan Temsil Heyeti'nin bu uyarıyı göz ardı etmeyeceği de katidir.

Seçimlerde Ekim ayı geride bırakılmış ve Kasım ayında sancakta yeni isimler aday gösterilmiştir. Bu isimler arasında eski Aydın Valisi Nureddin Paşa da vardır. Nureddin Paşa ile birlikte sancaktan başka isimlerde aday gösterilmiştir. 7 Kasım'da gazetelerde yer alan "Taşra Mebus Namzedleri" haberiyle adayların isimleri halka duyurulmuştur:

"Dün milli kongrede firka siyasiye merhuslart ictimâ ederek muhtelif firkaların taşra mebus 
namzedleri listeleri tedkik edilmiş ve müșteriken kabul edilecek namzedler hakkında devir ve diraz müzakerat icra edildikden sonra liste takrir etdirilerek taşralarada tebliği olunmuşdur. Milli kongrede kabul edilen taşra mebus namzedleri esamisi ber veche âtîdir: Aydın: Mütekaedin askeriyeden Hafiz Reşid Beg, Ziraat müthesislerinden Salih Zeki Beg, Nureddin Paşa (Yenigün, 7 Teşrinisani 1335, s.2).

Nurettin Paşa sadece Aydın'dan değil İzmir'den de aday gösterilmiştir. Aynı şekilde Temsil Heyeti'nin adayı olan Hüseyin Kazım Bey'de Aydın'ın yanı sıra İzmir'den aday gösterilen isimler arasındadır (Sabah, 6 Teşrinisani 1335, s.1; Yenigün, 5 Teşrinisani 1335, s.2). Hatta bu dönem Nazilli'de Aydın Jandarma Tabur Kumandanı olarak görev yapan Abidin Bey 15 Kasım 1919 tarihinde Hüseyin Kazım Bey’e bir telgraf göndererek telgrafında öncelikle dokuz aydan beri teşkilatla uğraştığını ve bu süreçte on beş bin mücahide ulaştıklarını söyleyerek bu hususta başarılı olduklarını belirtmiştir (ATASE Arşivi, Atatürk Koleksiyonu, K:59, G:86, B:86-1). Telgrafinda ayrica Harbiye Nezareti'nin kendisinden malumat alamaya çalıştığını bildirerek İzmir'den de aday gösterilmesine rağmen Yunanlıların işgali yüzünden buradaki adaylığının sona erdiğini bildirmiştir. Abidin Bey telgrafının devamında Hüseyin Kazım Bey'e Aydın Sancağından da aday gösterildiğini ve burada iki kazadan tam oy aldığını bildirmiştir. Bunun yanı sıra diğer üç kazadan da kazanma ihtimalinin yüksek olduğunu belirtmiştir. Seçimlerde "Fırkacılık yoktur vatanın müdafaası vardır." şeklindeki konuşmasını bitirirken, kendisinden Aydın'dan adaylı̆̆ını devam ettirmesini istemiş̧tir (ATASE Arşivi, Atatürk Koleksiyonu, K:198, G:79, B:79aa).

Kasım ayı sonlarına gelindiğinde Aydın Sancağında seçimler bitmiş ve mebuslar belli olmuştur. Seçim sonuçları gazetelerde yayınlanmış ve buna göre 4 Aralık 1919 tarihi itibarı ile oy çokluğu ile sancaktan üç mebus seçilmiştir. Sabık-ı Şehir Emini Hüseyin Kazım Bey, İzmir Müdafaa-i Hukuk Cemiyeti Kâtib-i Umumisi Cami Bey ve Bozdoğan Müftüsü Emin Efendi sancaktan seçilen mebuslardır (İkdam, 4 Kânunuevvel 1335, s.1; Illeri, 4 Kânunuevvel 1335, s.7).

Seçimler bitmiştir lakin seçilen mebuslar Temsil Heyeti tarafından sevinçle karşılanmamıştır. 57. Tümen komutanı Albay Şefik Aker'in seçimlerin sonuçlandığ günlerde verdiği malumatta bunu açıkça doğrulamaktadır. Oda Aydın seçimlerinde hayal kırıklığına uğradığını belirtmiştir. Aker aynı zamanda Hürriyet ve İtilaf Fırkası'nın önemli bir avantaj elde ettiğinin de altını çizmiştir. Zira firkanın meclise mebus göndermesi aynı zamanda Misakı Milli kararlarının alınması karşısında bir red oyunun daha olması anlamına gelmektedir:

"Aydın milletvekili seçimi hakkında sırası gelmişken bilgi vermek yerinde olacaktır. Bu tarihlerde Temsil Heyeti üyelerinden Albay Refet bölgemize henüz gelmişti. Nazilli merkezinde o dönemler duruma hâkim olanlar, yani Demirci Mehmet Efenin nüfuzunu kullanmak isteyenler Hürriyet ve İtilaf Partisi üyeleriyle hiçbir partiye bağll olmayan (...) Bey idi. Bunlar kendi üyelerini milletvekilliğine seçtiler. Albay Refet'i de klramadılar. (...) Bey ve onun arzu ettiği bir iki kişi milletvekilliğine seçilmişti. Hürriyet ve İtilaf partisine bağlı olanların milletvekili seçilmesi bizi üzmüşı̈̈... Bu sırada Temsil Heyeti 27 Aralık 1919'da Ankara'ya gelmişti”' (Aker,2006:382).

Mebusların belli olmasından sonra sıra İstanbul'a hareket etmelerine gelmiştir. Ancak daha önce Ankara'da yapılacak olan toplantıya katılmaları gerekmektedir. Mustafa Kemal Paşa 31 Aralıkta Nazilli Jandarma Tabur Kumandanı Abidin Bey ile Nazilli Umûm Kuvâ-yı Milliye Kumandanı Demirci Mehmet Efe'ye haber göndererek 13-14 Aralık'ta kendisine gönderdikleri şifreleri Ankara'ya varınca aldığını ve Ankara'dan ayrılmasına imkân olmadığı için seçilen mebusları Ankara'ya davet ettiğini bildirmiştir. Ayrıca telgrafında mebusların 
Ankara'ya gelebilmeleri için gerekenlerin yapılmasını istemiștir (ATASE Arşivi, Atatürk Koleksiyonu, K:24, G:96, B:96bd). Albay Aker Temsil Heyeti'nin Ankara'ya 27 Aralıkta geldiğini belirtmiş ancak Aydın mebuslarının hangi tarihte bu toplantıya katıldıkları hakkında bilgi vermemiştir. Mebuslarının Ankara'ya ve oradan İstanbul'a geçiş tarihleri tam olarak bilinmemektedir. Nitekim 12 Ocak 1920 tarihinde İstanbul'da Son Osmanlı Meclis-i Mebusanı açılmış (M.M. Z.C, c. 1, D. 4, İçs.1,İn.1, 12 Kânunusani 1336, s.4) ancak Aydın mebuslarının mazbataları 26 Ocak 1920 tarihli üçüncü oturumda onaylanmıştır ( M.M. Z.C, c. 1, D. 4, İçs.1,İn.3, 26 Kânunusani 1336, s.30).

\section{Aydın Mebuslarının TBMM'ne Katılması}

16 Mart 1920 tarihinde Meclis-i Mebusan'ın İngilizler tarafından işgal edilmesinden sonra Mustafa Kemal Paşa meclisin Ankara'da açılacağını bildirmiş, vilayet ve sancak merkezlerine ayrıca kolordu kumandanlarına gönderdiği tebliğ ile her livadan meclise beş mebus seçilmesi istemiştir. Aydın Sancağından seçilen Cami Bey ile Emin Bey Ankara'ya gelerek TBMM'ne katılmıştır. Hüseyin Kazım Bey ise meclisin dağıtılmasından sonra bir süre açıkta kalmıştır. Ancak kendisi Mustafa Kemal Paşa'nın çağrısı ile toplanan TBMM'de yer almamıştır. Sadece daha sonra meclisin toplandığı yıl Aralık 1920'de Mustafa Kemal Paşa ile içlerinde İsmet Pasa, Ahmet İzzet ve Bahriye Nazırı Salih Paşa'nın da bulunduğu heyet ile Bilecik Görüşmelerine katılmıştır (Kadri,1991:17).

\section{Menteşe Sancağında 1919 Seçimleri}

Menteşe Sancağı da işgallerden etkilenen bölgeler arasındadır. İşgaller devam ederken 1919 seçim hazırlıkları da başlamıştır. İtalyan işgalinde bulunan Muğla'nın Fethiye kazası Yunanlılar tarafindan işgal edilen bölgelere nazaran daha sakin olduğu için seçim merkezi olarak burası kabul edilmiştir (Türkeş,1978:76-78). Seçimlerde Muğla halkı sadece işgallerle uğraşmak zorunda kalmamıştır. Bu süreçte bölgenin iki büyük gücü Demirci Mehmet Efe ile Yörük Ali Efe'nin Muğla ve havalisi üzerindeki nüfuz çekişmesi de bölgeyi en az işgaller kadar olumsuz etkilemiştir. Zira Kuvâ-yı Milliye hareketinde muhacir, asker toplama, vergi, mahkeme işleri, seçimler ve Heyet-i Milliyenin bu bölgelerdeki merkezlerinin çalışması gibi birçok faaliyet efeler sayesinde yürütülmektedir. Aralarında yaşanan dargınlığın bu faaliyetlerin hepsini etkileyeceği muhakkaktır. Muğla'daki Müdafaa-i Hukuk Merkezi reisleri özellikle Yörük Ali Efe ile Kuvâ-yı Milliye'nin bölgedeki faaliyetleri hakkında fikir alışverişi yapmaktadır. Dahası 1919 Ağustos'undan sonra Yörük Ali Efe güney Aydın bölgesi komutanı olmuş, düzenli ordunun kurulmasından sonra seçimlerde dâhil olmak üzere Bodrum, Milas, Muğla, Müdafaa-i Hukuk Merkezleri ile işbirliği yapmıştır (Akça,2000:2831).

Bölgede bir yandan efelerin gücü kontrol altında tutulmaya çalışılırken, diğer yandan da Ali Rıza Paşa Hükümeti seçim kararı almış ve seçimler başlamışıı. Bunun üzerine Mustafa Kemal Paşa 10 Ekim 1919 tarihinde Menteşe Mutasarrıflı̆̆ına bir telgraf göndererek sancakta seçim hazırlıklarının başlamasını ve seçimler konusunda olabildiğince dikkatli davranılmasını istemiştir. Ayrıca adaylar belli oldukça isimlerinin zaman kaybedilmeden Sivas'a bildirilmesi gerekmektedir (ATASE Arşivi, Atatürk Koleksiyonu, K:20, G:206, B:206ad). Dâhiliye Nezareti de aynı şekilde 16 Ekim'de tüm sancak ve vilayet merkezlerine seçim genelgesi yollamıştı. Temsil Heyeti İstanbul Hükümeti de seçimleri kontrol altında tutmaya çalışıyordu. Zira gönderilen bu yazıda seçim bölgelerinde seçimlerde uyulması gereken hususlar bildiriliyor ( BOA. DH. İ.UM. EK. 114/39-16) ayrıca seçimleri denetlemek üzere merkezden müfettişler gönderileceği belirtiliyordu. Heyetlerin bilhassa askeri ve idari güçlerin seçimlere müdahale ederek adaylarını kazandırmak için nüfuz kullanmalarının engelleneceği yazıyordu. Mustafa Kemal Paşa ve Temsil Heyeti ise bu konuda hükümetin 
tepkisini çekmemek için temkinli davranıyor ancak istedikleri adayların seçilmesi için de ellerinden geleni yapıyordu (BOA. DH. İ.UM. EK. 114/39-5).

Menteşe Sancağından aday olan ilk isim Temsil Heyeti tarafında aday gösterilen Hüseyin Ragıp Bey olmuştur. Çanakkale Müstahkem Mevki Komutanı Miralay Şevket Bey 20 Ekim 1919 tarihinde Sivas'a Mustafa Kemal Paşa'ya “Nuh Bey'e” şifresiyle gönderdiği telgrafında Hüseyin Ragıp Bey'in Menteşe Sancağından aday olduğunu bildirmiş ve bu ismin seçilmesi için gerekenin yapılmasını istemiştir. Şevket Bey telgrafında ayrıca seçimlere hiçbir şekilde müdahale etmeyeceklerine dair hükümete söz verdiklerini eklemiştir (ATASE Arşivi, Atatürk Koleksiyonu, K:20, G:206, B:206bk).

1919 seçimlerinde genel olarak ülkenin her yerinde İttihatçılar ile İtilafçılar arasında büyük bir mücadele verildiği söylenebilir. Bununla birlikte Hürriyet ve İtilaf Firkasının Kuvâ-yı Milliye ruhunun egemen olduğu Muğla'da pek faal olamadığı görülmektedir. Ancak Muğla'da firkanın politikasını benimseyen isimler her zaman var olmuştur. Muğla'da Hürriyet ve İtilaf Fırkası ancak 1919 yılının Mart ayında faaliyete geçebilmiştir. Önce Muğla Şule-i Meşrutiyet Kulübü adı altında açılmış daha sonra da tüm muhalifleri çatısı altında toplayarak Hürriyet ve İtilaf Fırkası adını almıştır. II. Meşrutiyetin ne kadar mahkûm ettiği Itttihad-ı Muhammed-i Cemiyetinin ortada kalmış müridi varsa üyeliğe kabul edilmiştir. Akşehirlizade Hilmi Efendi müftüzade Saadettin Bey (Muğla eski sandık emini) ve Hasan Çavuşzade Bekir ağa, Dava vekili Mercanzade Hamdi Bey, Hac Memiş Ağazade Şerif Efendi, Menzilcizade Yakup Efendi, Hacıçakıroğlu aşit Efendi, Cinci Tayyar, Koçağalı Vahit Hoca Muğla'da firkanın önde gelen isimleri olmuştur. Fırkanın Muğla yöneticilerinden bazıları fırkanın Kuvâ-yı Milliye aleyhinde faaliyetlerine karşı, Kuvâ-yı Milliye tarafına geçerek ulusal mücadeleye destek vermiştir. Bir dönem Hürriyet ve İtilaf firkasının Muğla reisliğini yapan Müftüzade Sadettin Efendi bütün Kuvâ-y1 Milliye komitelerine girmiş, Muğla'nın Nazilli delegeliği yapmış ayrıca daha sonra TBMM'de Muğla'yı temsil etmiştir. Mecliste Mustafa Kemal Paşa'ya karşı oluşan diğer gruba da katılmamıştır (Türkeş,1978:7882).

Hürriyet ve İtilaf Fırkasının tersine İttihat ve Terakki Fırkası ise Muğla'da kurulan ilk siyasi fırkadır. Celal Bayar tarafından örgütlenmeye başlayan fırka 1908 seçimlerinden önce kurulmuştur. Ulalı Hamza Hayati Bey ve Milas'lı Halil Menteşe'nin temsil ettiği firkaya daha sonra Muğla eşrafindan birçok önemli isimde katılmıştır. Muğla İttihat ve Terakki Fırkası liva başkanı Murat Bey, Osmanlı Mebusan Meclisi reisi Halil Menteşe, Osmanlı Mebusan Meclisi Üyesi Hamza Hayati, Muğla Belediye Başkanı Zorbazzade Ragıp Bey, Dava vekili Muğla Fırka Reisi Sinanzade Mehmet Cemal Artuç yazar Bestekâr Hacı Kadızade Sabri Bey, beyin cerrahisi operatörü Dr. Cemil Şerif Baydur, imam hatipli Bozüyüklü Hacı Süleyman Efendi, Ahi köy başkanı Yatağanlı Fehmi Bey, orman mühendisi Kemal Kara Muğla, askeriye memur Kocakatip M. Tevfik Kuran, il genel meclis üyesi Berberoğlu Akif Bey, hukuk fakültesi öğrencisi İskender Alper, istatistik memuru Tokuçoğlu Ömer Azmi Efendi, çiftçi gazeteci Zorbazzade Emin Kamil Bey, çiftçi Gölcüklü oğlu Şevket Bey ve Dava vekili Ali ipekoğlu Bekir Bey’ler fırka için çalışmalar yapmış önemli isimlerdir. $\mathrm{Bu}$ isimler aynı zamanda II. Meşrutiyet döneminde yapılan seçimlerinde Muğla'dan meclise seçilen mebuslardır. Ancak ilk kurucuları arasından bazı isimler daha sonra Hürriyet ve İtilaf Fırkasına geçmiştir (Pancar,2010:48; Türkeş,1978:359). Albay Aker de Menteşe seçimlerinde yaşanan bu mücadeleyi "İtilaf - İttihat sürtüşmesi de yeniden filizlendi" sözleriyle doğrulamıştır. Aker ayrıca sözlerinin devamında Demirci Mehmet Efe'nin İtilafçıların nüfuzuna girerek Köşk'ten Nazilli'ye gittiğini, Kazım Nuri Bey'i yüz bin lira vermesi için Köşk'te zeybekler tarafından hapsedildiğini, Celal Bayar ve Şükrü Saraçoğlu gibi vatansever isimlerden Aydın Kuvâ-yı Milliyesi'nin mahrum edildiğini, 
Umumi Kuvâ-yı Milliye Komutanı Hacı Şükrü Bey’i bir iki ay sonra attırdıklarını ve 1919 seçimlerinde Hürriyet ve İtilafçıların mebus seçmelerine sebep olduklarını söylemiştir. Menteşe Sancağında 1919 seçimlerinde İttihat -İtilafçı mücadelesinde devam ederken Ragıp Bey ile Hamza Bey'in mebus olma mücadelesi de eklenince esnaf kepenk kapatmak zorunda kalmış ve olası bir çatışma için tedbir almaya çalışmıştır. Aslında Hamza Bey Hürriyet ve İtilaf Fırkası üyesi değildir. Nitekim seçimlerde Menteşe'den tek aday olmak istemektedir (Türkeş,1978:358-359). Cavit Bey ise Hamza Bey'in Meclisi Mebusan seçimlerinden çekilmesini ve Yörük Ali Efe'nin Muğla'yı terk etmesini istemektedir. Bu yüzden Hamza Bey'e bir haber yollayarak olayın ancak bu şekilde kapanabileceğini ve Demirci Mehmet Efe kuvvetlerinin Muğla'ya gelmekten vazgeçeceğini bildirmiştir. Nitekim Yörük Ali Efe ve amcası Hamza Bey bu teklifi reddetmiştir (Akça,2000:28-31).

Görüldüğü üzere Ragıp Bey ve Hamza Bey arasındaki mücadeleye efelerin de karışması bölgede büyük bir kargaşaya neden olmuştur. Kasım ayının ortalarına kadar devam eden bu gerginlik seçimlere de yansımış ve İttihatçı - İtilafçı çekişmesinin yaşandığı bu seçimlere Hacı Kadızade Hafız Sabri Bey Fethiye'ye memurlar göndermiş ancak vakit geçmeden Yörük Ali Efe'ye Sabri Bey'in Fethiye'de olduğu haber edilmiştir. Efeye ayrıca Sabri Bey ve yanındakilerin yapılacak mebusan meclisi seçimlerinde Menteşe Mutasarrıf Hilmi Bey ve Dersaadetli Baha Bey'in seçilmesi için çalıştığı bilgisi verilmiştir (Türkeş,1978:345-349). Bunun üzerine Yörük Ali Efe halkın serbest oy kullanması ve daha çok Hamza Bey'in seçilebilmesi için Temsil Heyeti'nden Sabri Bey'in tutuklamasını istemiştir. Efenin bu isteğine karşılık Fethiye Heyet-i Milliye Reisi Vasfi Bey 17 Kasım'da Sabri Bey ve yanındakilerin korumalarla birlikte Muğla'ya gönderildiğini haber etmiştir (Türkeş,1978:9394). Sabri Bey ise daha sonra Yörük Ali Efe'ye haber yollayarak Kuvâ-y1 Milliye harekâtında her zaman onun yanında olduğunu belirtmiş ve aslında Fethiye'ye gitmesinin asıl sebebinin Fethiye ahalisinin tahsilât, asker toplama gibi konularda gerekli çabayı göstermek olduğunu söylemiștir. Bunun üzerine Temsil Heyeti Sabri Bey'in bundan sonra herhangi bir propaganda yapması halinde derhal tutuklanacağını bildirmiştir (Pancar,2010:48-49; Türkeş,1978:345-348). Bununla birlikte kayıtlarda Sabri Bey hakkında tutuklatma kararı isteyen tek kişinin Yörük Ali Efe olmadığını görülmektedir. Muğla Heyet-i Milliye Reisi Mehmet Hilmi Bey'de 17 Kasım 1919'da Hafız Sabri Efendi'nin Sivas'a yolladığı bir telgraf yüzünden tutuklanmasını talep etmiştir. Zira Sabri Efendi kendi hattıyla 23 Ekim 1919 tarihinde mühürsüz ve imzasız olarak gönderdiği telgrafta üç yıl boyunca Menteşe'de Milli Mücadele için çalıştığını ve ayrıca mutasarrıf Hilmi Bey'in görevden alınmasının son derece haklı olduğunu iddia etmiştir (ATASE Arşivi, Atatürk Koleksiyonu, K:24, G:96, B:96at). Ona göre Hilmi Bey'in yerine atanan Ali Bey memleket için daha hayırlıdır. Oysaki gönderdiği telgraf hem mühürsüz hem de diğer azaların imzaları bulunmamaktadır. Yani buda kendi başına aldığı bir karar olduğunu göstermektedir. Bu yüzden Heyet-i Milliye Reisi Mehmet Hilmi Bey Temsil Heyeti’nden Hafiz Sabri Efendi hakkında soruşturma başlatılmasını istemiştir (ATASE Arşivi, Atatürk Koleksiyonu, K:24, G:96, B:96au).

Hafız Sabri Bey meselesinin halen devam ettiği Menteşe seçimlerinde Kasım ayının ortalarına gelinmiş ve seçilen adaylardan Yusuf Bey ile Bodrum Heyeti Milliye Reisi, 16 Kasım 1919 itibarı ile sancakta müntehib-i sani seçimlerinin bittiğini bildirmiştir (Güneş,2018:640). Böylece Kasım ayının sonlarına doğru merkez sancaktan seçilen isimler belli olmuştur. Bu sonuçlara göre Hüseyin Ragıp Bey, Çiftçiler Derneği adına Milaslı Doktor İsmail Hakkı Bey ve fetvayı hane mübeyyizlerinden Yakup Bey, Milas ceza reisi sabıkı Fehmi Bey, Milas Kuvâ-yı Milliye Reisi Halil İbrahim Menteşe, Bekir Sıtkı ve Hamdi Beyler, Dersaadet Reji Nazırı sabıkı Bahaddin Bey, İzmir muhacirin müdebbiri Faik Bey 
mülkiye mekteplerinden Hilmi beyler Muğla'dan aday olarak gösterilmiştir (İkdam, 24 Teşrin-i Sani 1335, s.2).

Görüldüğü üzere adaylar arasında Menteşe Mutasarrıfı Hilmi Bey’de vardır. Mustafa Kemal Paşa tarafından seçilmesi istenen isimler ise Menteşe Mutasarrıf Hilmi Bey, eski Reji Nazırı Baha Bey ve Trabzon Mülkiye Müfettişi Hilmi Beylerdir (Türkeş, 1978:359-360). Özellikle Mutasarrıf Hilmi Bey sancaktan seçilmesi istenen ilk isimdir. Zira kendisi Muğla'dan Sivas kongresine delege olarak katılmıştır (ATASE Arşivi, Atatürk Koleksiyonu, K:29, G:96, B:96ar). Dahası Kuvâ-yı Milliyenin çalışmalarına destek verdiği ve İttihatçıları desteklediği için Dâhiliye Nezaretinden Harbiye Nezareti'ne gönderilen bir tezkere ile görevinden alınmıştır. Hilmi Bey'in çalışmaları hükümet tarafından devlet işlerine müdahale olarak değerlendirilmiştir. Bu yüzden Demirci Mehmet Efe Hilmi Bey'in baştan beri Kuvâ-yı Milliye taraftarı olduğunu belirtmiş ve seçimlerde de kendisini desteklediğini bildirmiştir. $\mathrm{Bu}$ nedenle Temsil Heyeti için Hilmi Bey seçimlerde önemli bir isimdir (BOA. DH-KMS. D:53, G:67, B.1-2; ATASE Arşivi, Atatürk Koleksiyonu, K:29, G:96, B:96ar). Buna mukabil Kasım ayının sonlarında biten seçimlerde Hilmi Bey seçilen mebuslar arasına girememiştir. Hilmi Bey'in durumu Demirci Mehmet Efe tarafindan 13 Aralık 1919'da Nazilli'den Mustafa Kemal Paşa'ya çekilen bir telgrafla bildirilmiş ve Hilmi Bey'in bazı mühim sebeplerden dolayı Muğla'dan mebus olarak seçilemediği belirtilmiştir. Demirci Mehmet Efe telgrafının devamında Nazilli Heyet-i Milliyesinden Hilmi Bey'in Antalya Mutasarrıfı Cemal Bey'in yerine tayin edilmesi için Harbiye Nezaretine bir yazı yazıldığını söylemiştir. Temsil Heyeti'nden de eğer kendisi gibi Hilmi Bey'in dürüst ve güvenilir bir kişi olduğunu düşünüyorsa bunu Dâhiliye Nezareti'ne bildirmelerini istenmiştir (ATASE Arşivi, Atatürk Koleksiyonu, K:29, G:96, B:96ba).

Demirci Mehmet Efe'nin bu telgrafına cevap olarak Mustafa Kemal Paşa efeye ulaştırılmak üzere 31 Aralık 1919'da Nazilli'de bulunan Aydın Jandarma Tabur Kumandanı Abidin Bey'e bir telgraf göndermiş ve öncelikle Mutasarrıf Hilmi Bey'in mebus seçilememesinden dolayı duyduğu üzüntüyü anlatmıştır. Mustafa Kemal Paşa telgrafın devamında kendisi ile aynı fikirde olduğunu ve hükümete gereken yazının yazıldığını da bildirmiştir. Ancak aldıkları cevapta durumun muhakeme edilmek istendiği cevabını almıştır (ATASE Arşivi, Atatürk Koleksiyonu, K:29, G:96, B:96be). Görüldüğ̈̈ üzere Menteşe Mutasarrıfı Hilmi Bey'in mebus seçilememiş olması Demirci Mehmet Efe'yi de Temsil Heyeti'ni de üzmüştür. Bu yüzden Milli esaslar için görev yapabileceği bir konuma getirilmeye çalışılmıştır.

Menteşe seçim sonuçları Kasım ayının sonlarında belli olmuş ve sancaktan İttihat ve Terakki Fırkası ile Hürriyet ve İtilaf Fırkasından birer mebus olmak üzere iki mebus seçilmiştir. Bu seçimlerde Hürriyet ve İtilaf Fırkası isteğine ulaşmış ve adeta 1912 seçimlerinin acısını çıarmıştır. Seçimlerin sonunda Hürriyet ve İtilaf Fırkası taraftarları Halil İbrahim Efendiyi, (Türkeş,1978:359-360) İttihat ve Terakki Fırkası üyeleri ise Ardahan Mutasarrıfı Bodrumlu mülki müfettişlerden Ethem Efendizade Mustafa Hilmi (Uran) Bey’i mebus olarak seçmiş̧ir (Güneş,2018:640). Hürriyet ve İtilafçıların adayı Milaslı Müderris Halil İbrahim Efendi'nin seçimlerde başarılı olmasında bölgede yaşanan karışıklık önemli bir rol oynamıştır. Zira İbrahim Efendi'nin karşısında güçlü bir rakip yoktur. Menteşe seçimlerine İttihatçılar kendi aralarında bölünmüş, İtilafçılar ise birlik halinde girmişlerdir. Bu kutuplaşmayı gören Hamza Bey ise Temsil Heyeti'nin göstermiş olduğu diğer adayların kimlikleri karşısında direndiği takdirde kendisinin de İtilafçı olarak gösterileceğini anlamış ve seçimlerden çekilmiştir. Mebusların belli olmasıyla sıra meclise doğru hareket etmelerine gelmiştir. Menteşe mebuslarının İstanbul'a gitmeden önce Ankara'daki toplantıya uğrayıp uğramadıkları hakkında herhangi bir bilgi bulunmamaktadır (Türkeş,1978:359-360). 12 Ocak 1920'de meclisin açılması ile ilk oturuma yetişebilen mebuslar yeminlerini ederek göreve başlamıştır. 
Menteșe mebuslarının ilk oturumda hazır bulunduğu görülmektedir. Ancak hangi tarihlerde İstanbul'a geldikleri hakkında kesin bilgi bulunmamaktadır. Bununla birlikte Menteşe mebuslarının 3 Şubat 1920 tarihli yedinci oturumla 12 Şubat tarihli oturumda yeminlerinin kabul edildiğini görülmektedir (M.M. Z.C, c. I, D. 4, İçs.1, İn.7, 3 Şubat 1336, s. 60. M.M. Z.C, c. I, D. 4, İçs.1, İn.8, 9 Şubat 1336, s. 95).

\section{Sonuç}

Sonuç olarak I. Dünya Savaşından sonra imzalanan Mondros Mütarekesi Türk halkının kaderinin belirlenmesinde önemli rol oynamıştır. Yaşanan haksız işgaller ve meclisin kapalı olması halka direnişten başka yol olmadığını göstermiştir. Bu nedenle Mustafa Kemal Paşa ile Temsil Heyeti etrafında toplanan halk Müdafaa-i Hukuk Cemiyetleri kurarak, teşkilatlanmaya başlamıştır. Mustafa Kemal Paşa ve Temsil Heyeti bu süreçte Müdafaa-i Hukuk Merkezleri ve Sivas arasında irtibatı sağlayarak seçimlere giden süreci en doğru şekliyle koordine etmeye çalışmıştır. Vilayet ve sancak merkezlerinde kurulan Müdafaa-i Hukuk Merkezlerinin zamanı gelince seçim merkezi olarak görev yapması Temsil Heyeti adına hayati bir görevi yerine getirdiğini göstermiştir. Aynı şekilde mutasarrıflıkların Dâhiliye Nezareti için bu görevi üstlenmesi halkın her iki bağlamda kenetlendiğinin göstergesi olmuştur. Bu açıdan bakıldığında 1919 seçimleri hem Milli Mücadele taraftarları hem de İstanbul Hükümeti yanlısı Osmanlı tebaası için birlikte çıktıkları kurtuluş yolunun ilk adımı olmuştur. Oldukça mühim bir cephede, Batı Anadolu Bölgesinde gerçekleşen seçimler ise ayrı bir önem arz etmiştir. Nitekim batı bölgelerindeki halk başta Yunan mezalimine olmak üzere birçok işgalci güce karşı hayatta kalma mücadelesi verirken bir yandan da 1919 seçimlerine hazırlık yapmıştır. Mustafa Kemal Paşa ve Temsil Heyeti ile birlikte halkın örgütlenmesinde ve işgallere karşı koymasında etkili olan Müdafaa-i Hukuk Merkezleri ve ayrıca efeler seçimlere giden süreçte Batı Anadolu halkının yanında olmuştur. Buna mukabil efelerin seçim sürecinde kendi adaylarını seçtirmek için verdiği mücadele halkı olumsuz etkilemiştir. İşgallerin her bölgede fazlasıyla hissedildiği bu dönemde halk güvence olarak gördüğü efelerin seçimlere karışmasına 1lımlı bakmamıştır. Zira seçim sürecinde Aydın ve Menteşe halkı İttihat ve İtilaf mücadelesinin ortasında kalmış ve efelerinde bu olaylara karışmasıyla seçimlerde beklenilen özveriyi gösterememiştir. Özellikle Temsil Heyeti adına Osmanlı İmparatorluğu'nda bir dönüm noktası olan bu seçimlerde halkın seçimlerde bekleneni yerine getirememesi, Hürriyet ve İtilaf Fırkasının bölgeden mebus çıkarmış olması teşkilatlanma çalışmalarının bir nevi yetersiz kaldığının da göstergesi olmuştur. Nitekim tüm bu olumsuzlukların gölgesinde 1919 seçimleri Aydın ve Menteşe Sancaklarında Aralık ayı sonlarına kadar yapılmış, Ardahan Mutasarrıfi Bodrumlu Mustafa Hilmi (Uran) ve Halil İbrahim Efendi Menteşe'den, Hüseyin Kazım Bey, Cami Bey ve Bozdoğan Müftüsü Emin Efendi Aydın'dan mebus olarak seçilmeyi başarmıştır. Sonuçların açıklanmasıyla her iki sancakta da hayal kırıklıkları yaşanmıştır. Özellikle Menteşe'den Halil İbrahim Efendi'nin Hürriyetçilerin adayı olarak seçimi kazanması Temsil Heyeti ve İttihat Terakki Fırkasını hem üzmüş hem de endişelendirmiştir. Bununla birlikte bölgede yaşanan işgallere nazaran seçimlerin iptali söz konusu olmadan bitmesi ve Meclis-i Mebusanın açılma sürecine girilmesi herkesi umutlandırmışıır. Bu bağlamda Son Osmanlı Mebusan Meclisi seçimleri daha öncede belirttiğimiz gibi Kurtuluş Savaşı'nın en önemli süreci olmuştur. Halk sığındığı Temsil Heyeti ve Mustafa Kemal Paşa cephesinin galibiyetini görmüş ve bundan sonraki süreçte de Cumhuriyet'e doğru emin adımlar atmıştır. 


\section{Kaynakça}

\section{Arşiv Belgeleri}

ATASE Arşivi, Atatürk Koleksiyonu, K:24, G:96, B:96ad.

ATASE Arşivi, Atatürk Koleksiyonu, K:20, G:206, B:206-ad.

ATASE Arşivi, Atatürk Koleksiyonu, K:24, G:96, B:96ae.

ATASE Arşivi, Atatürk Koleksiyonu, Kol. K:24, G:96, B:96aea.

ATASE Arşivi, Atatürk Koleksiyonu, K:24, G:96, B:96asa

ATASE Arşivi, Atatürk Koleksiyonu, K:198, G:79, B:79aa.

ATASE Arşivi, Atatürk Koleksiyonu, K:2, G:58, B:58ac.

ATASE Arşivi, Atatürk Koleksiyonu, K:24, G:96, B:96ah.

ATASE Arşivi, Atatürk Koleksiyonu, K:59, G:86, B:86-1.

ATASE Arşivi, Atatürk Koleksiyonu, K:24, G:96, B:96ai.

ATASE Arşivi, Atatürk Koleksiyonu, K:24, G:96, B:96ak.

ATASE Arşivi, Atatürk Koleksiyonu, K:24, G:96, B:96an.

ATASE Arşivi, Atatürk Koleksiyonu, K:24, G:96, B:96aq.

ATASE Arşivi, Atatürk Koleksiyonu, K:29, G:96, B:96ar

ATASE Arşivi, Atatürk Koleksiyonu, K:24, G:96, B:96at.

ATASE Arşivi, Atatürk Koleksiyonu, K:24, G:96, B:96au.

ATASE Arşivi İstiklal Harbi Kataloğu, K:1, G:77

ATASE Arşivi, Atatürk Koleksiyonu, K:29, G:96, B:96ba.

ATASE Arşivi, Atatürk Koleksiyonu, K:24, G:96, B:96bd.

ATASE Arşivi, Atatürk Koleksiyonu, K:29, G:96, B:96be.

ATASE Arşivi, Atatürk Koleksiyonu, K:20, G:206, B:206bk.

ATASE Arşivi, Atatürk Koleksiyonu, K:20, G:206, B:206-bo.

ATASE Arşivi, Atatürk Koleksiyonu, K:29, G:96, B:96ar.

BOA. DH-KMS. D:53, G:67, B.1-2.

BOA. DH. İ.UM. EK. 114/39-5.

BOA. DH. İ.UM. EK. D:114, G:39-16.

TITE Arşivi, K:310, G:44, B:44-1.

TITTE Arşivi, K:297, G:49, B:49-1.

M.M. Z.C, c. 1, D. 4, İçs.1, İn.1, 12 Kânunusani 1336.

M.M. Z.C, c. 1, D. 4, İçs.1, İn.3, 26 Kânunusani 1336.

M.M. Z.C, c. I, D. 4, İçs.1, İn.7, 3 Şubat 1336.

M.M. Z.C, c. I, D. 4, İçs.1, İn.8, 9 Şubat 1336. 


\section{Gazete ve Süreli Yayınlar}

İkdam, 4 Kânunuevvel 1335.

İkdam, 24 Teşrin-i Sani 1335.

İleri, 4 Kânunuevvel 1335.

Sabah, 6 Teşrinisani 1335.

Yenigün, 7 Teşrinisani 1335.

Yenigün, 24 Teşrinievvel 1335.

Yenigün, 5 Teşrinisani 1335.

\section{Kitap, Makale ve Tezler}

AKÇA, B., (2000), "Milli Mücadele Döneminde Yörük Ali Efenin Muğla ve Havalisindeki Faaliyetleri”, Muğla Üniversitesi SBE Dergisi, Muğla.1(2):28-31.

AKER, M. Ş, 57. (2006), Tümen ve Aydin Milli Mücadelesi, Genel Kurmay Askeri Tarih ve Stratejik Etüt Başkanlığı Yayınevi, Ankara.

ATATÜRK, Mustafa Kemal, (2016) Nutuk, Türk Tarih Kurumu Yayınları, Ankara

BAYRAM İ., (2013), “Milli Mücadele'de Aydın'da Efelerin Rolü”, Karatekin Edebiyat Fakültesi Dergisi (Karefad) Ankara, 1(1): 127-150

BİLGEN, B., (2011), "Dönemin Basınına Göre 1919 Seçimleri ve Meclis-i Mebusan'ın Oluşturulması”, Yayımlanmamış Yüksek Lisans Tezi, Edirne.

ÇOLAK, F., (2015), I. Dönem TBMM'de İzmir Mebusları ve Faaliyetleri, Çağdaş Türkiye Tarihi Araştırmaları Dergisi, İzmir, 15 (31):107-155.

DEMIRYÜREK, Halim, (2018), "Kütahya Sancağında 1919 Osmanlı Meclis-İ Mebusan Seçimleri”, MCBÜ, Sosyal Bilimler Dergisi, Manisa,16(3): 520-544.

GÖKBEL, Asaf (2005), Milli Mücadele'de Aydın, Kolalı Matbaası, Aydın.

GÜNEŞ, İ., (2012), Meşrutiyetten Cumhuriyete Türkiye'de Hükümetler Programları ve Meclisteki Yankıları (1908-1923), Türkiye İş Bankası Kültür Yayınları, İstanbul.

GÜNEŞ, Günver, (2018), "Milli Mücadelede Bodrum ve Çevresi”, Belgi, Denizli, (15):634655.

HAYTOĞLU, E., (2011), Aydın Kuvâ-yı Milliyesinde Efe Ve Zeybekler”, Belgi, Kış, Denizli, (1):51-72.

KADRİ H. K., (1991), Meşrutiyet'ten Cumhuriyet'e Hatıralarım, Haz: İsmail Kara, İstanbul.

KARACA, T. N., (2004), Meclis-i Mebusan'dan Türkiye Büyük Millet Meclisine Geçiş Sürecinde Son Osmanlı Meclis-i Mebusan Seçimleri, Türk Tarih Kurumu Basımevi, Ankara.

ÖZTOPRAK İ., (1989), Türk ve Batı Kamuoyunda Milli Mücadele, Türk Tarih Kurumu Basımı, Ankara.

PANCAR, E. (2010), “Aydın ve Muğla Kuvâ-yı Milliye'si”, Dokuz Eylül Üniversitesi Atatürk İlkeleri Ve İnklâp Tarihi Enstitüsü, Doktora Tezi, İzmir. 
TOSUN, R.,(1996), Milli Mücadelede Sivas'ın Yeri ve Önemi, Atatürk Araştırma Merkezi Dergisi, Ankara, 12(34), Mart,67-86.

TÜRKEŞ Ü., (1978), Kurtuluş Savaşında Muğla, Yelken Matbaası, Muğla. 


\section{EKLER}

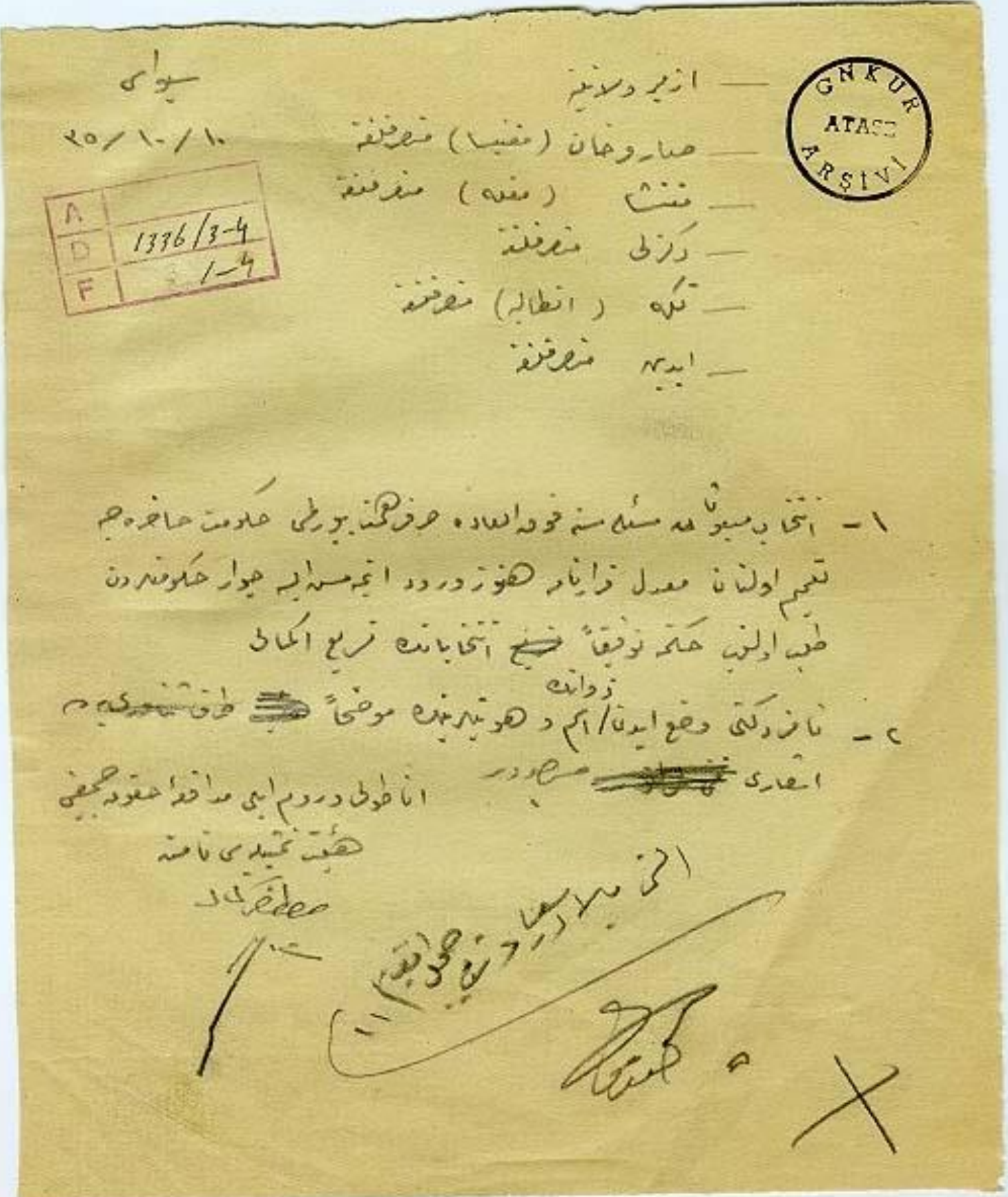

Ek 1: Menteşe Sancağından namzetliğini vaz eden zevatların Sivas'a bildirilmesi isteği. (ATASE Arşivi, Atatürk Koleksiyonu, K:20, G:206, B:206ad) 


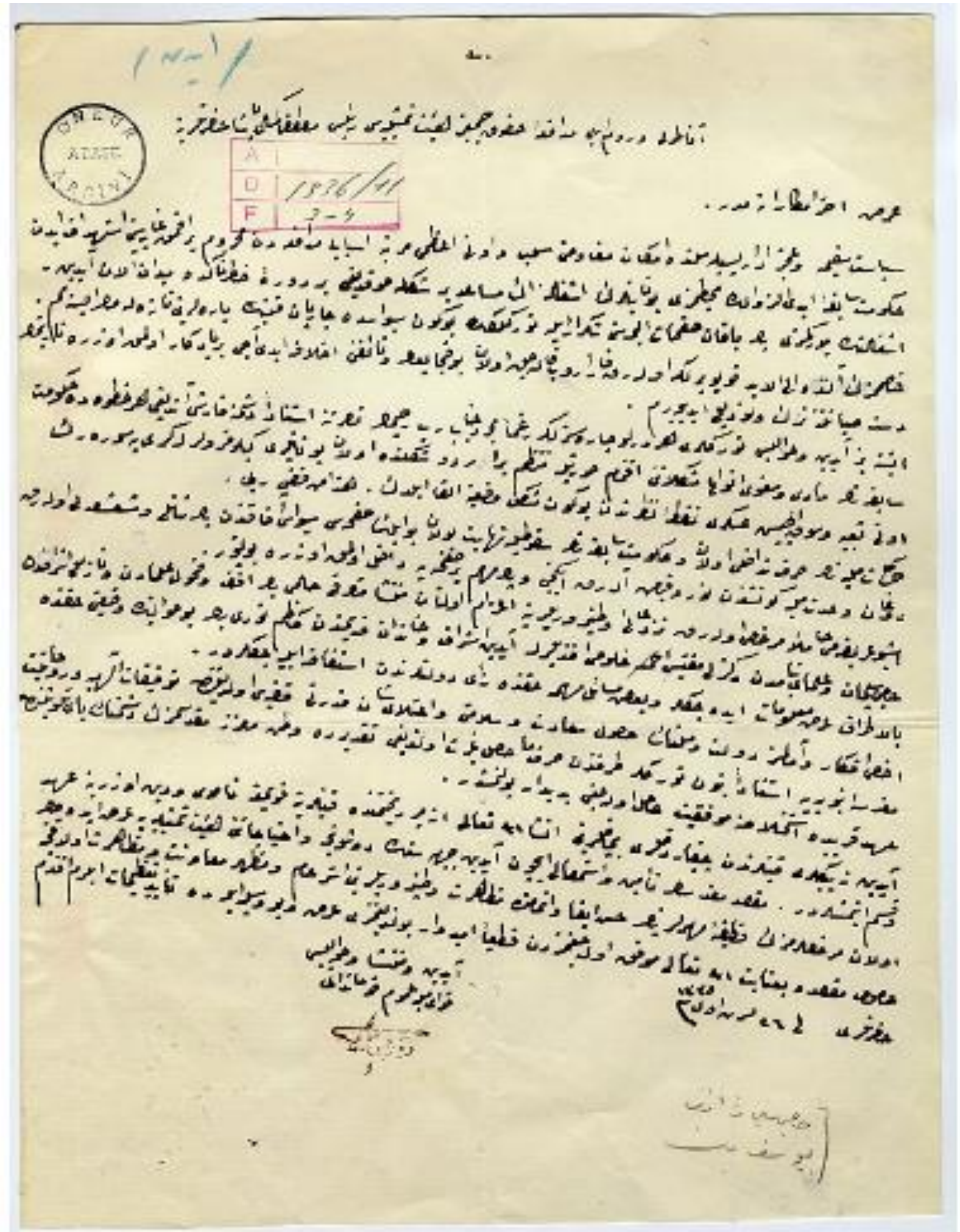

Ek 2, 3, 4, 5: Menteşe Mutasarrıfı Hilmi Bey, Nazilli eşrafından Hacı Süleyman Efendi, Denizli Müftüsü Ahmet Hulûsi Efendilerle Aydın eşrafından Kazım Nuri Beylerin Sivas Kongresine katılması ile alakalı belgeler.(ATASE Arşivi, Atatürk Koleksiyonu, K:24, G:96, B:96ad.) 


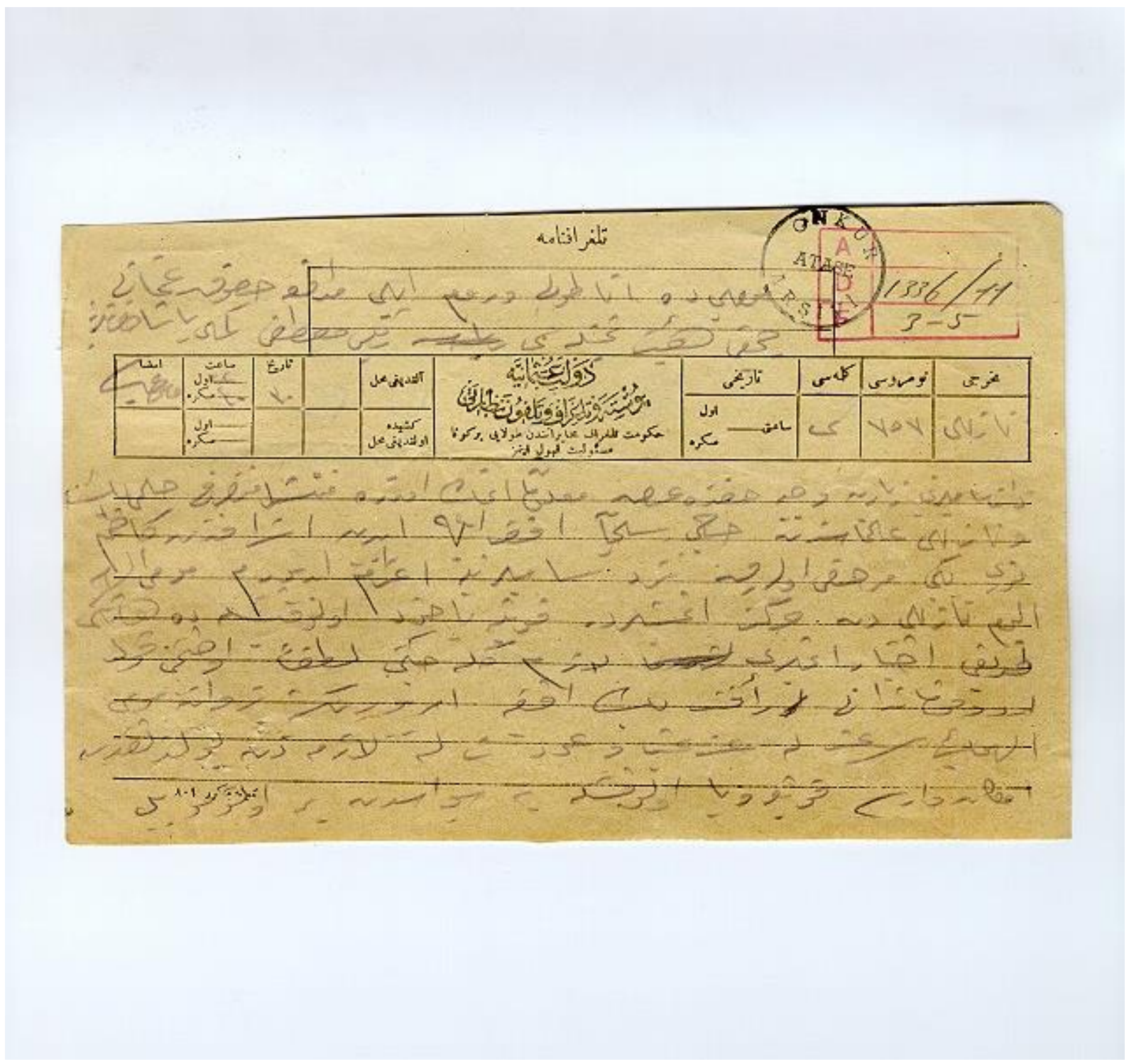

Ek 3: (ATASE Arşivi, Atatürk Koleksiyonu, K:24, G:96, B:96ae) 


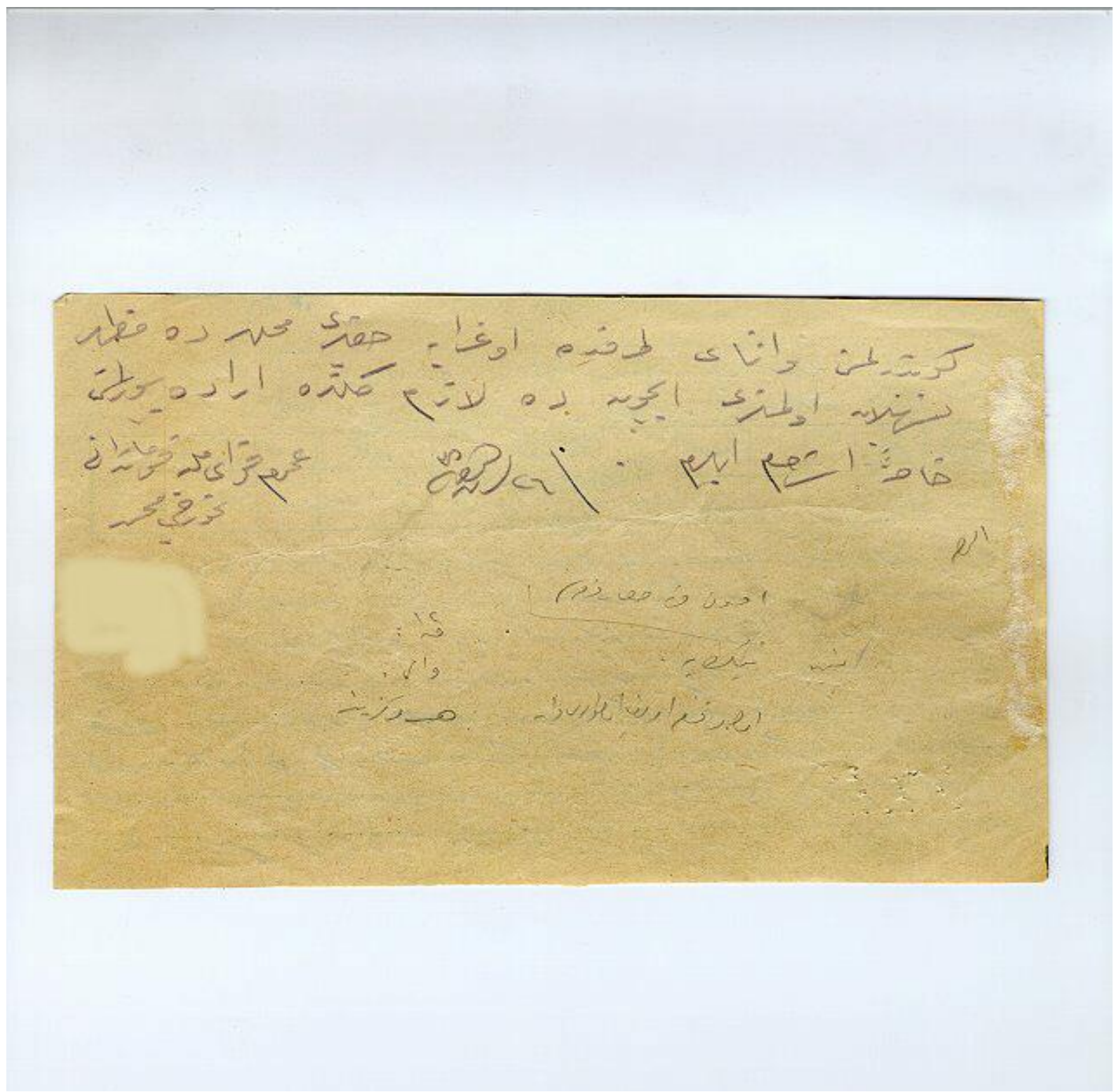

Ek 4: (ATASE Arşivi, Atatürk Koleksiyonu, Kol. K:24, G:96, B:96aea.) 


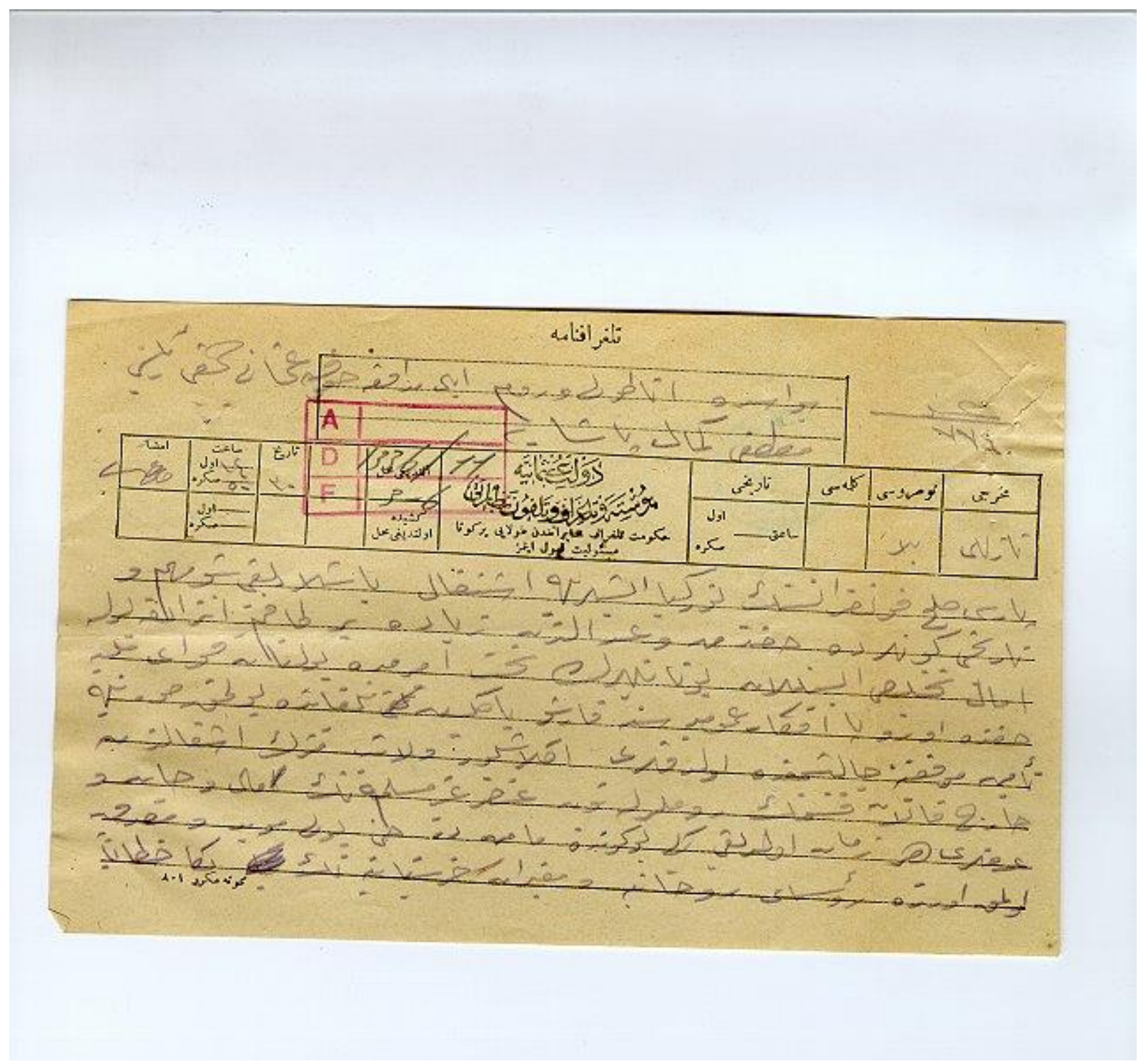

Ek 5: (ATASE Arşivi, Atatürk Koleksiyonu, K:24, G:96, B:96ah.) 


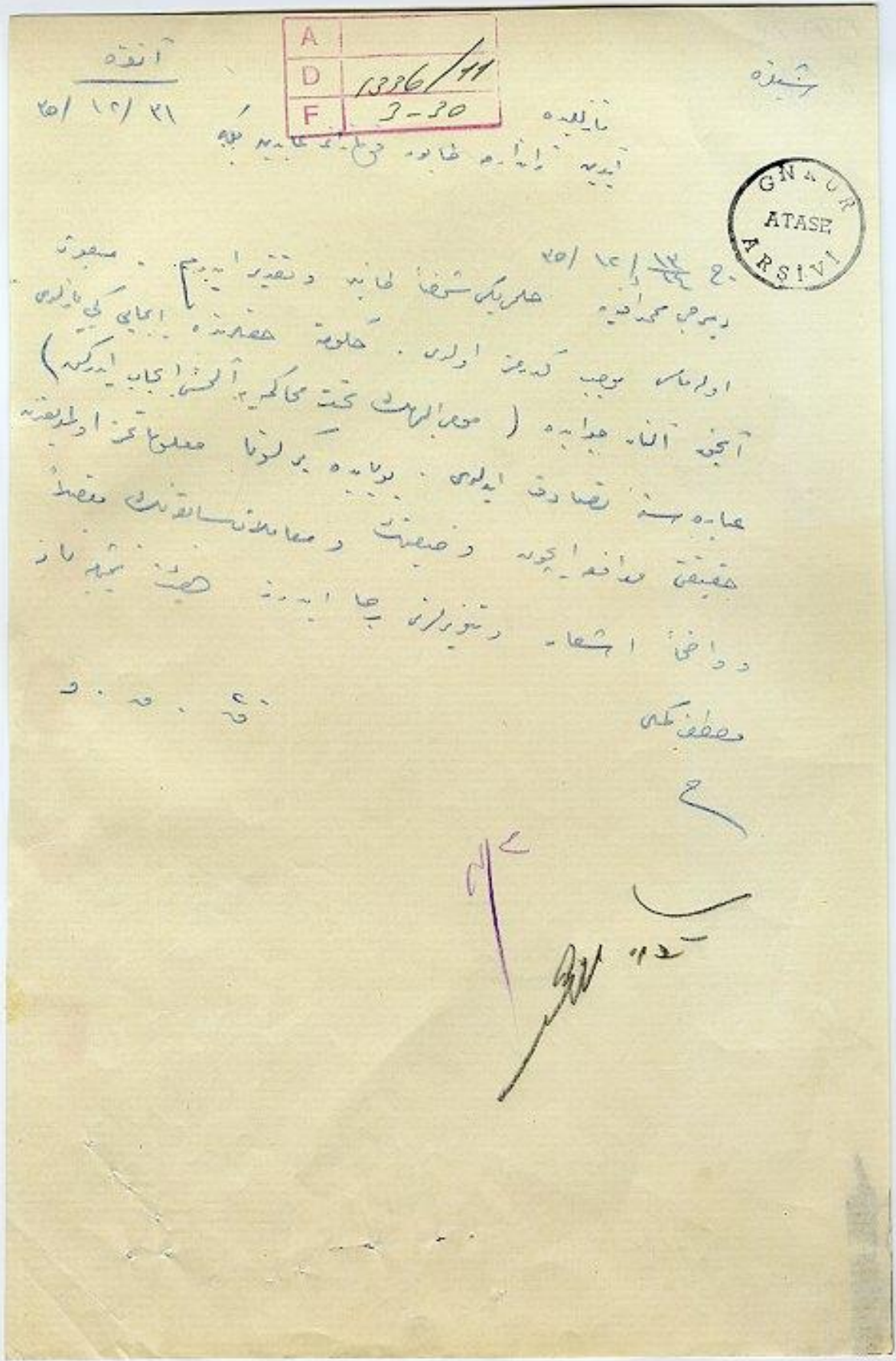


Ek 6: Temsil Heyeti namına Mustafa Kemal Paşa tarafindan Nazilli'de bulunan Aydın Jandarma Tabur Kumandanı Abidin Bey’e gönderilen şifre. (ATASE Arşivi, Atatürk Koleksiyonu, K:29, G:96, B:96be.) 